\title{
The Impact of Socioeconomic and Demographic Variables on Poverty: A Village Study
}

\author{
Imran Sharif Chaudhry", Shahnawaz Malik ${ }^{* * *}$ and Abo ul Hassan
}

\begin{abstract}
Poverty is a complex phenomenon based on a network of interlocking economic, social, political, and demographic factors. An understanding of the extent, nature, and determinants of rural poverty is a precondition for effective public policy to reduce poverty in rural Pakistan. The present study attempts to analyze the impact of socioeconomic and demographic characteristics of households on poverty, using primary data collected in the village of Betti Nala in Tehsil Jatoi, district Muzaffargarh in southern Punjab. We have used two distinct approaches: (i) a poverty profile, and (ii) an econometric approach in our empirical analysis. The results show that household size, dependency on household, participation, landholdings, and number of livestock have a significant impact on poverty incidence. Our final conclusion is that efforts should be made to improve socioeconomic factors in general and demographic factors in particular to alleviate rural poverty in remote areas of Pakistan, while land should be allotted to landless households.
\end{abstract}

JEL Classification: A13, C10, J19.

Keywords: Poverty, households, Punjab, Pakistan.

\section{Introduction}

Most societies have at some time in their development process seen a large number of people living in conditions of poverty, unable to afford the minimum essentials for a decent existence. Poverty, in this sense, has long been a historical fact and continues to be an unfortunate feature of life today. Nevertheless, poverty is not a new topic in development economics. Its alleviation has mostly been associated with high economic growth rates.

* , ${ }^{* * * *}$ Department of Economics, Bahauddin Zakariya University, Multan, Pakistan. 
Most poor people from less developed countries (LDCs) reside in rural areas and make their living from agriculture. The role of the agrarian structure and institutional settings in general and the rural poor in terms of socioeconomic and demographic factors in particular are of central importance in economic development. Traditionally, however, the agriculture sector and rural economy have been characterized, in most LDCs, by the predominance of a small landowning class, tenants, sharecroppers, and landless laborers who are at the core of the poverty problem. Moreover, rural areas are characterized by relatively low population densities, with maximum population thresholds in settlements.

The major emphasis of Pakistan's model of economic development has been on maximizing the growth of output, leaving too little to take care of mass poverty, socioeconomic disparities, and unfavorable demographic variables. The evidence suggests that Pakistan's economy has shown steady improvement in terms of major macroeconomic indicators. However, in spite of high rates of economic growth, Pakistan's poor, particularly its rural poor, have benefited very little.

A large number of studies on poverty in Pakistan and on rural poverty in particular are available. Most of these studies use data from the Household Income and Expenditure Surveys (HIES) and estimated measures of poverty. Almost all studies agree that rural poverty fluctuated around $40 \%$ during the 1960s, then declined in the 1970s and 1980s. The incidence of rural poverty increased in the 1990s, after which it showed a declining trend $^{1}$ [Naseem (1973), Irfan and Amjad (1984), Malik (1988), Amjad and Kemal (1997), Ali and Tahir (1999), Jafri (1999), Arif et al. (2000), Arif (2000) and Qureshi and Arif (2001)].

Patterns of poverty differ by province, and between rural and urban areas. The data consistently show that poverty is considerably higher in rural areas as compared with urban areas. Punjab accounts for almost $56 \%$ of the country's population. About $36 \%$ of its rural population is poor and ranks second-highest among the provinces. According to the estimates of the Federal Bureau of Statistics (FBS), 2002, about 40\% of the rural population in lower Punjab is poor, the highest incidence after rural NWFP. The International Fund for Agricultural Development (IFAD) (2001), also confirms that poverty is most severe and chronic in the rural areas of southern Punjab, NWFP, and Balochistan. Nevertheless, southern Punjab has received little attention, not only at the level of policy issues but also

\footnotetext{
${ }^{1}$ See Government of Pakistan, Pakistan Economic Survey, 2005-2006.
} 
empirical inquiry. The severity of the problem is the reason we have chosen to study a village in southern Punjab.

An understanding of the extent, nature, and determinants of rural poverty is a precondition for effective public action to reduce deprivation in the rural areas. The major objective of the present study is to analyze the impact of households' socioeconomic and demographic characteristics on poverty. The profile and correlates of rural poverty are also estimated in a bivariate analysis. The study is divided into five sections as follows: The conceptual framework of poverty and household's characteristics is given in Section II. Section III discusses the issues of data and methodology used in the present study. The results of a detailed profile of the correlates of rural poverty and econometric analysis are reported in Section IV. Section V presents conclusions and policy implications.

\section{Poverty and Household Characteristics: A Conceptual Framework}

\section{a. Concept of Poverty}

The persistence of poverty is linked to its multidimensionality: It is dynamic, complex, institutionally embedded, and a gender- and locationspecific phenomenon. The pattern and shape of poverty vary by social group, season, location, and country. There is much ambiguity in the way poverty is discussed by social scientists and analytically quantified by economists. Poverty means being deprived materially, socially, and emotionally. It steals the opportunity to have a life unmarked by sickness, a decent education, a secure home, and a long retirement [Oppenheim and Harker (1996), pp. 4-5].

Almost two and half decades ago, Amartya Sen (1981) addressed this issue in the context of persistent starvation in the midst of plentiful food stocks, noting that different social groups employ different means to gain access and control over food. The simple existence of sufficient food, he asserts, does not necessarily ensure access to that food. The means of securing access, which nearly always involves institutional interaction, are critical. Institutions limit or enhance poor people's rights to freedom, choice, and action [Sen $(1984,1999)]$.

The World Bank (1990) defines poverty as 'the inability to attain a minimum standard of living'. Later, the World Bank (2000) defines poverty as lack of command over commodities, or as a severe constriction of the choice set over commodities, leading to pronounced deprivation in well being or welfare. This definition is much broader and extends beyond food 
and nonfood items to include key assets and social determinants, which are essential for human development.

Lipton and Ravallion (1995) state that, "poverty exists when one or more persons fall short of a level of economic welfare deemed to constitute a reasonable minimum, either in some absolute sense or by the standards of a specific society".

The concept of poverty is not so easy to describe, however, it can be defined in the following general terms: (i) lack of 'means' in relation to 'needs,' i.e., absolute poverty, and (ii) lack of 'means' in relation to the 'means' of others, i.e., inequality or relative poverty. Poverty theorists advocated that the concept of absolute poverty is more relevant to the problems of developing economies than relative poverty. Thus, it is more appropriate to estimate and analyze absolute poverty in a developing country such as Pakistan where the average level of resources is limited.

\section{b. Concept of Poverty Lines}

A poverty line is that level of income or expenditure required by an individual to purchase or satisfy a minimum basket of consumption goods and services for him or her to be considered not in poverty. A poverty line is country-specific and this level of income or expenditure varies from one country to another. Irrespective of countries, households or individuals with a per capita income below this line are considered poor, and households with a per capita income above this line are considered nonpoor. Synonymously, a poverty line is an income level, which separates the poor from the nonpoor. Budget standards or the minimum needs approach was the earliest in setting the poverty line and has been used by Booth (1889) and Rowntree (1901). This approach involves the determination of a minimum quantity of various minimum needs or their money equivalent.

Poverty lines are therefore cutoff points separating the poor from the nonpoor. There are two main ways of setting poverty lines: relative and absolute. Most developing countries use an absolute rather than relative poverty line. In an absolute poverty line, the poverty threshold is established as the income level at which households are able to purchase essential food and nonfood items, including social services. This poverty line is fixed in terms of a living standards indicator and over the entire domain of the poverty comparison.

Ravallion (1993, p. 30) defines an absolute poverty line as "one which is fixed in terms of living standards, and fixed over the entire domain 
of the poverty comparison", while a "relative poverty line, by contrast, varies over that domain, and is higher than the average standard of living". Different methods have been used in the literature to define absolute poverty lines [see Sen (1979), Deaton (1997), Ravallion and Bidani (1994), Ravallion (1994) and Wodon (1997)].

In this study, we have not calculated an independent poverty line. We have used the poverty line adopted by Malik $(1992,1996)$ and adjusted it using the CPI of annual changes in prices (Pakistan Economic Survey, 2005-2006). The resultant rural poverty line is Rs895.78.

\section{c. Measurement of Poverty}

Once the conceptual problems in identifying either a nutritional norm or bundle of basic minimum needs are resolved and a poverty line has been developed or inflated, the next issue is the determination of an appropriate poverty index. Since the work of Sen (1976), taking into account inequality among the poor and not solely the incidence or average intensity of poverty has become common scientific practice. Much of the literature on the development of poverty indices has focused on whether indices are decomposable across population subgroups. This has led to the identification of a subgroup of poverty indices known as the class of decomposable poverty indices'. These indices have the property of being expressible as a weighted sum (more generally, as a separable function) of the same poverty indices assessed across population subgroups. Most commonly they include the Foster, Greer, and Thorbecke (FGT) (1984) poverty indices, Clark, et al (1981) index, Chakravarty (1983) classes of indices and the Watts (1968) index.

The FGT class of poverty indices has become, in the last two and half decades, the most popular class of poverty indices used in theoretical and empirical studies of poverty. The perceived and mentioned advantages of the FGT class of indices in the literature are: its ethical flexibility (captured by the parameter $\alpha$ ), its decomposability across subgroups, and its simplicity of computation and understanding among others [Duclos et al. (2002)]. In other words, the FGT class of poverty measures can be disaggregated for population subgroups and the contribution of each subgroup to national poverty can be calculated. The measures of poverty depth and poverty severity provide complementary information on the incidence of poverty.

$$
\mathrm{P}_{\alpha}\left(\mathrm{Y}_{\mathrm{I}}, \mathrm{Z}\right)=\left(\frac{1}{\mathrm{~N}}\right) \sum_{\mathrm{i}=1}^{\mathrm{q}}\left[\frac{\mathrm{Z}-\mathrm{Y}_{\mathrm{I}}}{\mathrm{Z}}\right]^{\alpha}
$$


Where $z$ is the poverty line and $y_{i}$ is the per capita income of the $i_{\text {th }}$ poor.

For each $\alpha \geq 0$, if $\alpha=0$, then $\mathrm{p}_{0}$ is simply the headcount ratio (also called incidence of poverty), while with $\alpha=1, p_{1}$ is a re-normalization of the income-gap measure (also called poverty gap). Finally the sensitive measure $\mathrm{p}_{2}$ is obtained by setting $\alpha=2$ (called severity of poverty).

\section{d. Understanding the Determinants of Rural Poverty}

The determinants of poverty can be macroeconomic or microeconomic. Our study is concerned with microeconomic variables and characteristics.

\section{Economic Characteristics of Households}

Economic characteristics include employment, income, consumption spending and household property and assets.

\section{i. Household Employment}

There are several indicators that determine household employment. Within this array of indicators, economists focus on the rate of participation in the labor force, the real rate of unemployment, and job changes. The participation rate is the first of the two employment variables used in the analysis. According to Lipton (1983), the higher the illness, disability, income per capita, intensity in customs and religious beliefs, status, the general welfare level and asset holdings, the lower the participation rate in LDCs. In comparing the nonpoor and poor, the positive incentive given by poverty to participation outweighs the negative effect on it; hence, the poor participate more than the nonpoor. In the present study, the participation rate is defined as the ratio of the number of workers to the number of adults in a household. In accordance with the argument given above, the participation rate is expected to be negatively correlated to poverty.

\section{ii. Household Incomes}

Income represents a very important area of consideration when characterizing the poor. The level of income is important not only for the households, but its distribution among household members and various socioeconomic groups. Income is difficult to define as it includes several components of which only some are monetary (for example, farm households consume most of their production onsite). Additionally, individuals tend to 
make false declarations about their income level, which is generally underestimated. It is possible in part to correct these declarations but only at the cost of carrying out a large-scale data-gathering operation on economic activities, the cost of production, factor inputs, and the prices of products. Given these limitations and the fact that savings are low, even zero, there is often a tendency to use a household's total spending as an approximation of its disposable income. Here, we calculate per capita expenditure per month as a proxy for household income.

\section{iii. Household Property and Assets}

The property of a household includes its tangible goods (land, cultivated areas, livestock population, agricultural equipment, machinery, buildings, household appliances, and other durable goods) and its financial assets (liquid assets and other financial assets). These indicators are of interest as they represent the household's inventory of wealth and therefore affect its income flow. Furthermore, certain households, especially in the rural areas of Pakistan, might be poor in terms of income but wealthy when their property is taken into consideration. This class of poverty is called secondary poverty by Rowntree (1901), as it applies to those who appear to have resources but have not been able to utilize them to raise themselves above the subsistence leve1. However, we will discuss household property and assets under the following heads.

\section{- Landholdings}

The ownership of agricultural land is considered the main factor that can extricate a household/individual from poverty. The variable or characteristic used in this study is the extent of landholdings per household in acres. This incorporates owner-cum-sharecroppers as well as sharecroppers. On the basis of the role it plays in a rural economy, we hypothesize a positive relation to the per capita income variable. Some technological and agricultural input variables (use of tractor, HYVs, fertilizer and pesticides, and irrigation water, etc.) are also associated with landholdings and have also a positive relation to per capita income.

\section{- Livestock Population}

The livestock sector is an important sector of the rural economy in Pakistan. The contribution of the livestock sector toward family income is quite substantial. In the present study, this form of property or asset is normally included and measured in monetary units. It also has a positive relation with per capita income in our analysis. 


\section{- Physical Assets}

Physical assets contribute significantly to per capita income. In the present study, physical assets occur in the form of agricultural equipment and machinery, i.e., tractors and accessories, etc., and household appliances such as electronic goods. These are measured in terms of the rupee value of total physical assets.

\section{Social Characteristics of Households}

Aside from economic indicators, we also have recourse to social indicators to characterize poverty and household living standards. The social indicators generally selected are health, education, and shelter.

\section{i. Health within the Household}

Four types of indicators are normally used to characterize health in analyzing a household's living standards. These indicators include (i) nutritional status (for example, anthropometric indicators such as weight for age, height for age, and weight for height); (ii) disease status (for example, infant and juvenile mortality and morbidity rates as related to certain diseases such as malaria, respiratory infections, diarrhea and sometimes poliomyelitis); (iii) the availability of healthcare services (primary healthcare centers, maternity facilities, hospitals and pharmacies, basic healthcare workers, nurses, midwives, doctors and traditional healers; and (iv) medical services such as vaccinations, access to medicines and medical information, and the use of these services by poor and nonpoor households. It is generally believed that drinking water and sanitation also influence health and nutritional status. Research shows that the poor are extremely disadvantaged in their access to safe sources of water supply and sanitation. Another indicator of housing standards is access to electricity.

\section{ii. Education}

According to human capital models, education is an important dimension of the nonhomogeneity of labor. High educational attainment may imply a greater set of employment opportunities and specifically in the rural context, a better awareness of the full potential of new agricultural technologies and associated agricultural practices. Four types of indicators are normally used to characterize education in an analysis of household living standards. These include the number of household members, level of education (literacy rate, with poor households having lower literacy), availability of educational services (primary and secondary schools), the use 
of these services by members of poor and nonpoor households (children's enrollment in school, dropout rate of children by age and gender and reasons for dropping out, percentage of children who are older than the normal age for their level of education and average spending on education per child registered) and educational codes. In the present study, educational attainment data is translated into a point system according to the following procedure:

No education for a household member --------------- 0 points

Education completed up to secondary level --------- 5 points

Education completed up to college or university ---- 10 points

The educational index is constructed by dividing the total number of educational points by household size. This variable is considered a major cause of poverty and points are given to those household members who have completed their education up to secondary level or higher; these members are observed as being older than 14 years and are assumed to be adults ${ }^{2}$. In view of its potential role, we hypothesize a positive relationship with per capita income, and a negative one with poverty incidence.

\section{iii. Shelter}

Shelter refers to the overall framework of the personal life of the household. It is evaluated by three components: housing, services, and the environment. Housing indicators include the type of building (size and type of materials, i.e., mud and straw, and baked and unbaked bricks); the means through which one has access to housing; and household equipment. Service indicators focus on the availability and use of drinking water, communication services, electricity, and other energy sources (wood, kerosene, dung cakes, etc.). Finally, environmental indicators concern the level of sanitation (mentioned earlier), the degree of isolation (availability of roads and paths which are usable at all times, length of time taken and availability of transportation to get to work) and degree of personal safety. Type and quality of housing are the result of poverty but also contribute to being poor in terms of unhygienic and unhealthy conditions. It is also established that poor households live in more precarious, poorer sanitary environments, which contribute to the poorer health and lowered productivity of household members and aggravates poverty at existing levels. The variable of housing conditions is taken into account to capture this important issue. On the

\footnotetext{
${ }^{2}$ For more details, see Malik (1996).
} 
contrary, better housing environment leads to good health and becomes the cause of increasing household income levels and reducing poverty.

\section{Demographic Characteristics of Households}

Aside from economic and social indicators, we make use of significant demographic indicators to characterize poverty and household living standards. The demographic characteristics of the household can be broadly classified into three categories, as follows:

\section{i. Household Size and Structure}

This indicator is an important one as it shows a possible correlation between the level of poverty and household composition. Household composition, in terms of the size of the household and characteristics of its members (such as age), is often quite different for poor and nonpoor households. The Pakistan Integrated Household Survey of 1998/99 shows that the poor tend to live in larger households with an average family size of 8.4 persons in the poorest quintile compared with 6.2 in the nonpoor quintile. Similar patterns are found in most developing and low-income countries (Malik 1992). Generally it is recognized that more healthy, educated, and adult members in a household contribute to their income levels and reduce poverty; if household members are not adult and educated, they can become the cause of poverty. It is hypothesized that the larger the household size, the higher the level of poverty incidence, and vice versa.

\section{ii. Dependency Ratio}

For a given household size, a larger number of children and elderly members would imply a smaller number of earners in the household. In the present analysis, the dependency ratio is calculated as the ratio of the number of members below 15 and over 64 to other household members. Furthermore, child and older member dependency ratios are also calculated using the same formula. This ratio allows us to measure the burden on members of the labor force within the household. One might expect that a high dependency ratio would be correlated positively with the level of rural household poverty.

\section{iii. Female-Male Ratio}

The female-male ratio or sex ratio is important in a household in determining the attitude toward work. Although not to be assumed a generalization, female household members in rural Pakistan are often 
constrained by cultural norms from working outside their household. This suggests that a high female-male ratio might be related to household poverty.

\section{iv. Age and Gender of Household Head}

The age and gender of the household head are also important in determining the attitude toward employment. It is widely believed that the age and gender of the household head significantly influences rural poverty. The age of the household head has a similar role to sex composition, as discussed above.

\section{Data and Methodology}

In this study, we make use of primary data collected through a household survey in the villages of Chah Qaisar and Kande Wala in Betti Nala, tehsil Jatoi, district Muzaffargarh. The format of the household questionnaire, covering broad aspects of each household's socioeconomic, demographic, and village-specific characteristics, is such that the information could easily be transformed on an individual basis. The modes of household survey data collection are as follows:

(i) Direct questioning of household head and other members;

(ii) Extracting data from participant observation; and

(iii) Interviewing of selected informants.

The household survey was conducted in May and June 2006. The village was characterized by a scattered population. Muzaffargarh district forms one of the southern parts of the province of Punjab and is situated between the Chanab and Sindh rivers. The river Chanab separates the district of Muzaffargarh from the district of Multan. District Muzaffargarh comprises four tehsils, namely, Muzaffargarh, Kot Addu, Jatoi, and Ali Pur. The population of Muzaffargarh district is around 2.8 million with a $52 \%$ male and $48 \%$ female population. About $74 \%$ of the total population resides in rural areas. Overall, the literacy rate is $29 \%$; the male literacy rate is $40 \%$ while the female literacy rate is only $14 \%{ }^{3}$.

We use two distinct approaches, namely bivariate and multivariate analyses. A bivariate analysis of household characteristics can be performed to analyze the correlates of the rural poverty profile. Moreover, the rural

\footnotetext{
${ }^{3}$ Figures are taken from different documents of the District Government.
} 
poverty profile focuses on presenting the poverty characteristics of various rural household groups. According to Gillespie (1990)

The effectiveness of poverty studies could be improved by presenting poverty profiles based on information, which is relevant to policy objectives [Gillespie (1990), p. 3].

Poverty measures are the most common and popular approach to presenting a poverty profile to assess how various household groups contribute to overall rural poverty. We employ FGT indices as discussed earlier to calculate a detailed rural poverty profile. The most commonly used poverty measures of FGT indices are the incidence of poverty, depth of poverty, and poverty severity. Hence, a detailed rural poverty profile can be constructed using FGT indices in terms of the socioeconomic and demographic characteristics of households.

In our econometric analysis, we will carry out a multivariate income regression and alternatively a logit model on the potential determinants of rural poverty in terms of a household's socioeconomic and demographic characteristics. These models will be estimated using household data at the village level. The methodology of multivariate income regression models is used extensively by many researchers ${ }^{4}$. In income regressions, the logarithm of income (possibly divided by the poverty line) is typically used as the dependent variable (indicator of well-being). The explanatory variables span a large array of possible poverty determinants along the lines of those discussed in the last section.

The income regression equation can be written in the following form:

$$
\operatorname{Ln} w_{i}=\beta_{o}+\sum \beta_{j=1} X_{k i}+U_{i}
$$

Where

$$
\begin{aligned}
& \text { Ln } \mathrm{w}_{\mathrm{i}}=\text { Natural } \log \text { of per capita expenditures divided by the poverty } \\
& \text { line }^{5} \\
& \mathrm{X}_{\mathrm{ki}}=\text { A set of household characteristics }
\end{aligned}
$$

\footnotetext{
${ }^{4}$ See for example, Glewwe (1990), Grosh and Munoz (1996), Kozel (2000), Ravallion (1996), Ravallion and Huppi (1991), and Wodon (2000, 2001).

${ }^{5}$ The log of per capita expenditures is divided by poverty line to normalize the explained variable.
} 


$$
\begin{aligned}
& \beta_{\mathrm{k}}=\text { Parameters } \\
& \mathrm{U}_{\mathrm{i}}=\text { A random disturbance term }
\end{aligned}
$$

In employing an income regression model, the next step is to construct variables for the model. Here we present the list of selected variables relating to the income regression model of the determinants of rural poverty model in Table-1.

\section{Table-1: List of Variables for the Determinants of Rural Poverty}

\begin{tabular}{|c|c|}
\hline Variables & Variables' Description \\
\hline \multicolumn{2}{|c|}{ Dependent Variable } \\
\hline $\ln w_{i}$ & $\begin{array}{l}\text { Natural log of per capita income expenditures divided by } \\
\text { the poverty line }\end{array}$ \\
\hline \multicolumn{2}{|c|}{ Explanatory Variables } \\
\hline HSIZE & Size of the household \\
\hline EDUC & Educational codes (household education level) \\
\hline PARR & Participation rate \\
\hline FMRM & Female-male ratio (member) \\
\hline FMRW & Female-male ratio (worker) \\
\hline DEPR & Dependency ratio \\
\hline CDEPR & Child dependency ratio \\
\hline ODEPR & Old dependency ratio \\
\hline AGEH & Age of the household head (years) \\
\hline $\mathrm{AGEH}^{2}$ & Age of the household head squared \\
\hline PPRM & Persons per room in a household \\
\hline PLSTO & Population of livestock per household \\
\hline VPAST & $\begin{array}{l}\text { The value of physical assets per household in rupees } \\
\left({ }^{\prime} 000\right)\end{array}$ \\
\hline LHOL & Landholding per household (area in acres) \\
\hline
\end{tabular}
Model (Income Regression Model) 
It has also become standard practice to analyze the determinants of poverty alternatively through categorical regressions such as the logit and the probit, which are nonlinear probability models. There are some appropriate uses of these models in poverty assessments. First, for targeting analysis, these regressions can be used to assess the predictive power of various variables used for means testing. Second, when panel data are available, these regressions can also be used to analyze the determinants of transient versus chronic poverty. However, the present study is concerned only with the logit model. According to the basic principles of discrete choice models, econometric modeling consists of confronting two alternative and mutually exclusive situations, being considered poor or not. In a logit model, the endogenous variable is a dichotomous or dummy variable, with (1) representing the household as poor and (0) if the household is not poor.

The exogenous variables are taken as the socioeconomic and demographic characteristics of households. The present study follows more or less the same methodology as used by Malik (1996) and Arif et al. (2000) but with different data. The list of the variables for logistic estimates of rural poverty determinants is given in Table- 2 . 
Table-2: List of Variables for the Logistic Estimates of Socio-Economic and Demographic Factors Affecting Rural Poverty

\begin{tabular}{|c|c|}
\hline Variable & Variables' Description \\
\hline \multicolumn{2}{|c|}{ Dependent Variable } \\
\hline POV & $\begin{array}{l}=1 \text { If the household is extremely poor } \\
=0 \text { Non-poor or otherwise }\end{array}$ \\
\hline \multicolumn{2}{|c|}{ Explanatory Variables } \\
\hline HSIZE & Size of the household \\
\hline DEPR & Dependency ratio \\
\hline FMRM & Female-male ratio (member) \\
\hline HHFM & $\begin{array}{l}=1, \text { If household head is female, } \\
=0 \text { if male }\end{array}$ \\
\hline HHLT & $\begin{array}{l}=1 \text { If the household head is literate, } \\
=0 \text { if illiterate }\end{array}$ \\
\hline HHFR & $\begin{array}{l}=1 \text { if household head is farmer, } \\
=0 \text { otherwise }\end{array}$ \\
\hline HHFL & $\begin{array}{l}=1 \text { If household head is agricultural laborer, } \\
=0 \text { otherwise }\end{array}$ \\
\hline HHLB & $\begin{array}{l}=1 \text { If household head is non-farm worker/laborer, } \\
=0 \text { otherwise }\end{array}$ \\
\hline AGEH & Age of the household head (years) ${ }^{6}$ \\
\hline HHRS & $\begin{array}{l}=1 \text { If the household resides in a Kacha house, } \\
=0 \text { if Pakka house }\end{array}$ \\
\hline EDUC & Education codes (household education level) \\
\hline PARR & Participation rate \\
\hline HVHC & $\begin{array}{l}=1, \text { If household member visits health center, } \\
=0 \text { otherwise }\end{array}$ \\
\hline LHOL & $\begin{array}{l}=1, \text { If household has land holding, and } \\
=0 \text { If landless }\end{array}$ \\
\hline PLSTO & Population of livestock per household \\
\hline PASTH & $\begin{array}{l}=1, \text { If household has physical assets, and } \\
=0 \text { otherwise }\end{array}$ \\
\hline
\end{tabular}

${ }^{6}$ Age squared variable is not included in logit model because most of the variables are binary and secondly does not have significant effect on poverty reduction when the dependent variable is binary. 


\section{Results and Discussions}

The household survey data indicates that households in the surveyed villages are mostly Saraiki-speaking with a small minority being Punjabispeaking. Infrastructure facilities are very poor: there is no basic health center, no metal road, sanitary conditions are very poor, and educational facilities are also not up to the mark. The village agricultural land is plain and mostly cultivable. The land tenure system consists of both ownercropping as well as share/rent-cropping. The main crops of the area are wheat, cotton, sugarcane, and maize. There are also some mangoes and pomegranate farms.

\section{a. Decomposition of Rural Poverty by Household Characteristics}

\section{A Bivariate Analysis}

Before discussing the decomposition of rural poverty by household characteristics, it is necessary to present the estimates of the rural poor using the FGT indices based on our household survey data. The estimates of rural poverty measures are given in Table- 3 .

Table-3: Rural Poverty Estimates of Households of a Village

\begin{tabular}{lc}
\hline Poverty Measures & Poverty Estimates \\
\hline Poverty Incidence (\%) & 48.00 \\
Poverty Depth & 0.247 \\
Severity of Poverty & 0.143 \\
\hline
\end{tabular}

Source: Calculated from the Household Survey Data, 2006.

According to the results of the poverty measures, $48 \%$ of households are poor. The poverty depth is about 24.7 which means that $24.7 \%$ of the poverty line is required to escape rural poverty. The severity of poverty is estimated at $14.3 \%$, implying that there is $14.3 \%$ inequality among the poor. Put differently, a higher weight is placed on those households who are further away from the poverty line. This indicates that how much of a gap is among the poor and what volume of resources is needed to bring these households closer to the poverty line or above it. The results for the incidence of poverty are in line with those of other studies ${ }^{7}$ on southern Punjab.

\footnotetext{
${ }^{7}$ For example, see FBS (2002), Malik (1996) and Chaudhry (2003).
} 
Next, we look at the profile of rural poverty by household characteristics such as size of landholding, household size, educational attainment, participation rate, dependency ratio, female-male ratio (members), female-male ratio (workers), and age of household head. The results are reported in Table- 4 to Table- 11 .

Table- 4 shows that the incidence of poverty is high among landless households: $58.3 \%$ of the poor are landless. About $27.1 \%$ of the poor are landowning households with 1 to 3.5 acres of land. As far as the acuteness of poverty is concerned, the poverty depth is $18.9 \%$. In other words, $18.9 \%$ of the poverty line is needed to escape from poverty for landless households. The severity of poverty is also very high (10.6\%) among landless households as compared with landowning households. Households with less than 3.5 acres are disproportionately poor. It is evident from the results that poverty incidence falls as the size of landholding increases.

The estimates in Table- 5 suggest that all poverty measures gradually increase with the increase in household size except those comprising 6 members. We can conclude that the household size found most prone to rural poverty is one with 7-8 and above members/households. There was no household consisting of 1 member in the total sample. Therefore, a household of 2 members ( $4 \%$ of the total population) escapes not only from the incidence of poverty but also from poverty depth and severity. A household of 8 or more members (26\% of the total household population) has the highest incidence, depth and severity of poverty. Rural poverty is more severe and sensitive among large households.

According to human capital models, education is an important dimension of nonhomogeneity of labor. To look into this more explicitly we decomposed the FGT indices of poverty in terms of levels of educational attainment. The results are given in Table-6. They suggest that the incidence of poverty, as well as its depth and severity are much higher among households with no educational attainment. The last two subgroups have the lowest level of incidence, depth, and severity of poverty. This implies that households with higher levels of educational attainment are correlated with a reduction in rural poverty.

The labor force participation rate is the prime variable of employment used in our analysis. The estimates reported in Table-7 show that, as the participation rate of households increases, the incidence; depth and severity of poverty fall. The third poor subgroup has the lowest severity of poverty with a high participation rate. 
We have also decomposed poverty in terms of the dependency ratio. The results are given in Table-8. We start with the dependency ratio, which has a significant impact on a household's well being. The results show that as the dependency ratio increases from the first to second category, the poverty incidence, depth and severity increase. Since these two categories make up two-thirds of the households, his tendency supports our hypothesis that poverty will be more severe among those households with a higher dependency ratio.

The gender issue also plays an important role in poverty analysis. To address this issue, we have developed female-male ratios for individuals and workers. The decomposition of poverty (FGT indices) in terms of these two different characteristics has been undertaken in Tables-9 and 10. Poverty is more severe in households that have a high female-male ratio of workers (see Table-10). This is mainly because females are engaged in the agricultural sector, where there is a large proportion of disguised unemployment.

The role of the age of the household head in poverty analysis also gives some interesting results and supports the current phenomenon of youth unemployment where considerable incidence, depth and severity of poverty are observed in Table- 11 . About $23 \%$ of households are in the age group 20-35 and poor. As this comes to $39 \%$ of the total household population, nearly half of the poor are in this age group. They need 12.7 percent of the poverty line to escape poverty. The incidence, depth and severity of poverty decrease as the age group of the household head increases, along with work experience and income.

Table-4: Decomposition of Poverty by Size of Landholdings

\begin{tabular}{lccccc}
\hline $\begin{array}{l}\text { Size of Land } \\
\text { (acres) }\end{array}$ & $\begin{array}{c}\text { As \%age } \\
\text { of Poor }\end{array}$ & $\begin{array}{c}\text { Households } \\
\text { (percent) }\end{array}$ & $\begin{array}{c}\text { Poverty } \\
\text { Incidence } \\
\text { (percent) }\end{array}$ & $\begin{array}{c}\text { Poverty } \\
\text { Depth }\end{array}$ & $\begin{array}{c}\text { Severity } \\
\text { of } \\
\text { Poverty }\end{array}$ \\
\hline Landless & 58.3 & 51.00 & 28.00 & 0.189 & 0.106 \\
$1-3.5$ & 27.1 & 20.00 & 13.00 & 0.053 & 0.031 \\
$3.6-7.0$ & 14.6 & 17.00 & 07.00 & 0.005 & 0.006 \\
7.1 and above & - & 12.00 & - & - & - \\
\hline
\end{tabular}

Source: Calculated from the Household Survey Data, 2006. 
Table-5: Decomposition of Poverty by Household Size by Members

\begin{tabular}{lccccc}
\hline $\begin{array}{l}\text { Household } \\
\text { Size }\end{array}$ & $\begin{array}{c}\text { As \%age } \\
\text { of Poor }\end{array}$ & $\begin{array}{c}\text { Households } \\
\text { (percent) }\end{array}$ & $\begin{array}{c}\text { Poverty Incidence } \\
\text { (percent) }\end{array}$ & $\begin{array}{c}\text { Poverty } \\
\text { Depth }\end{array}$ & $\begin{array}{c}\text { Severity of } \\
\text { Poverty }\end{array}$ \\
\hline 1 & - & 00.00 & - & - & - \\
2 & - & 04.00 & - & - & - \\
3 & 6.3 & 07.00 & 3.00 & 0.012 & 0.008 \\
4 & 12.5 & 13.00 & 6.00 & 0.028 & 0.015 \\
5 & 14.6 & 16.00 & 7.00 & 0.052 & 0.027 \\
6 & 18.8 & 14.00 & 6.00 & 0.031 & 0.019 \\
7 & 35.4 & 20.00 & 9.00 & 0.049 & 0.024 \\
8 and above & & 26.00 & 17.00 & 0.075 & 0.050 \\
\hline
\end{tabular}

Source: Calculated from the Household Survey Data, 2006.

Table-6: Decomposition of Poverty by Educational Attainment

\begin{tabular}{lccccc}
\hline $\begin{array}{l}\text { Education } \\
\text { Codes }\end{array}$ & $\begin{array}{c}\text { As \%age } \\
\text { of Poor }\end{array}$ & $\begin{array}{c}\text { Households } \\
\text { (percent) }\end{array}$ & $\begin{array}{c}\text { Poverty Incidence } \\
\text { (percent) }\end{array}$ & $\begin{array}{c}\text { Poverty } \\
\text { Depth }\end{array}$ & $\begin{array}{c}\text { Severity of } \\
\text { Poverty }\end{array}$ \\
\hline $0.00-0.00$ & 66.7 & 37.00 & 32.00 & 0.161 & 0.092 \\
$0.01-1.00$ & 20.1 & 16.00 & 10.00 & 0.064 & 0.028 \\
$1.01-3.00$ & 8.3 & 12.00 & 04.00 & 0.013 & 0.019 \\
3.01 and above & 4.2 & 35.00 & 02.00 & 0.009 & 0.004 \\
\hline
\end{tabular}

Source: Calculated from the Household Survey Data, 2006.

Table-7: Decomposition of Poverty by Labor Force Participation Rates

\begin{tabular}{lccccc}
\hline $\begin{array}{l}\text { Participation } \\
\text { Rates }\end{array}$ & $\begin{array}{c}\text { As \%age } \\
\text { of Poor }\end{array}$ & $\begin{array}{c}\text { Households } \\
\text { (percent) }\end{array}$ & $\begin{array}{c}\text { Poverty Incidence } \\
\text { (percent) }\end{array}$ & $\begin{array}{c}\text { Poverty } \\
\text { Depth }\end{array}$ & $\begin{array}{c}\text { Severity of } \\
\text { Poverty }\end{array}$ \\
\hline $0.00-0.33$ & 81.3 & 42.00 & 39.00 & 0.189 & 0.121 \\
$0.34-0.67$ & 14.6 & 37.00 & 07.00 & 0.045 & 0.013 \\
$1.68-1.00$ & 4.2 & 21.00 & 02.00 & 0.013 & 0.009 \\
\hline
\end{tabular}

Source: Calculated from the Household Survey Data, 2006. 
Table-8: Decomposition of Poverty by Dependency Ratio

\begin{tabular}{lccccc}
\hline $\begin{array}{l}\text { Dependency } \\
\text { Ratio }\end{array}$ & $\begin{array}{c}\text { As \%age } \\
\text { of Poor }\end{array}$ & $\begin{array}{c}\text { Households } \\
\text { (percent) }\end{array}$ & $\begin{array}{c}\text { Poverty Incidence } \\
\text { (percent) }\end{array}$ & $\begin{array}{c}\text { Poverty } \\
\text { Depth }\end{array}$ & $\begin{array}{c}\text { Severity of } \\
\text { Poverty }\end{array}$ \\
\hline $0.00-0.33$ & 25 & 30.00 & 12.00 & 0.063 & 0.036 \\
$0.34-0.67$ & 31.2 & 35.00 & 15.00 & 0.095 & 0.043 \\
$0.68-1.00$ & 16.7 & 13.00 & 08.00 & 0.041 & 0.026 \\
$\begin{array}{l}1.01 \text { and } \\
\text { above }\end{array}$ & 27.1 & 22.00 & 13.00 & 0.048 & 0.038 \\
\hline
\end{tabular}

Source: Calculated from the Household Survey Data, 2006.

Table-9: Decomposition of Poverty by Female-Male Ratio (Members)

\begin{tabular}{lccccc}
\hline $\begin{array}{l}\text { Female-Male } \\
\text { Ratio (Members) }\end{array}$ & $\begin{array}{c}\text { As \%age Households } \\
\text { of Poor }\end{array}$ & $\begin{array}{c}\text { Poverty Incidence } \\
\text { (percent) }\end{array}$ & $\begin{array}{c}\text { Poverty } \\
\text { (percent) }\end{array}$ & $\begin{array}{c}\text { Severity } \\
\text { Depth Poverty }\end{array}$ \\
\hline $0.00-0.50$ & 37.5 & 27.00 & 18.00 & 0.086 & 0.051 \\
$0.51-1.00$ & 43.8 & 38.00 & 21.00 & 0.113 & 0.062 \\
1.01 and above & 18.8 & 35.00 & 09.00 & 0.048 & 0.030 \\
\hline
\end{tabular}

Source: Calculated from the Household Survey Data, 2006.

Table-10: Decomposition of Poverty by Female-Male Ratio (Workers)

\begin{tabular}{lccccc}
\hline $\begin{array}{l}\text { Female-Male } \\
\text { Ratio (Worker) }\end{array}$ & $\begin{array}{c}\text { As \%age } \\
\text { of Poor }\end{array}$ & $\begin{array}{c}\text { Households } \\
\text { (percent) }\end{array}$ & $\begin{array}{c}\text { Poverty Incidence } \\
\text { (percent) }\end{array}$ & $\begin{array}{c}\text { Poverty } \\
\text { Depth }\end{array}$ & $\begin{array}{c}\text { Severity } \\
\text { of Poverty }\end{array}$ \\
\hline $0.00-0.33$ & 39.6 & 38.00 & 19.00 & 0.153 & 0.084 \\
$0.34-0.63$ & 31.3 & 33.00 & 15.00 & 0.072 & 0.051 \\
$0.64-1.00$ & 8.3 & 29.00 & 04.00 & 0.022 & 0.008 \\
\hline
\end{tabular}

Source: Calculated from the Household Survey Data, 2006. 
Table-11: Decomposition of Poverty by Age of Household Head

\begin{tabular}{lccccc}
\hline $\begin{array}{l}\text { Age of Household } \\
\text { Heads (Years) }\end{array}$ & $\begin{array}{c}\text { As \%age } \\
\text { of Poor }\end{array}$ & $\begin{array}{c}\text { Households } \\
\text { (percent) }\end{array}$ & $\begin{array}{c}\text { Poverty Incidence } \\
\text { (percent) }\end{array}$ & $\begin{array}{c}\text { Poverty } \\
\text { Depth }\end{array}$ & $\begin{array}{c}\text { Severity of } \\
\text { Poverty }\end{array}$ \\
\hline $20-35$ & 47.9 & 39.00 & 23.00 & 0.127 & 0.069 \\
$36-50$ & 25 & 27.00 & 12.00 & 0.059 & 0.036 \\
$51-65$ & 18.8 & 19.00 & 09.00 & 0.041 & 0.030 \\
66 and above & 8.3 & 15.00 & 04.00 & 0.020 & 0.008 \\
\hline
\end{tabular}

Source: Calculated from the Household Survey Data, 2006.

\section{b. Results of Multivariate Regression Models}

A village study data of 100 households is used to estimate the loglinear multivariate model. In order to check the impact of socioeconomic and demographic variables on rural poverty, a log linear multivariate model is estimated.

The empirical results show the explanatory power of the regression equations, as measured by $\mathrm{R}^{2}$, to be significantly high $\left(\mathrm{R}^{2}=79.50\right.$ and 80.30 , respectively in two equations). In other words, an average of $79 \%$ of the variation in the dependent variable (natural log of per capita income divided by poverty line) is due to the explanatory variables and the remaining $21 \%$ is due to other unmentioned variables. The joint or overall test of significance, F-test, is accepted at the $1 \%$ level of significance in all equations. All variables have the correct signs in the two equations. Not surprisingly, HSIZE, PARR and DEPR are significant at the $1 \%$ level in the two equations while, EDUC, FMRW, PPRM, PLSTO and LHOL are significant at the 5\% level. Empirically, we thus prove that socioeconomic and especially demographic variables have a significant impact on the income of households as well as on the reduction of poverty incidence in Pakistan in general and southern Punjab in particular. 
Table-12: The Determinants of Rural Income Per Capita or Poverty: Log-Linear Regression Results of a Village Data, 2006

\begin{tabular}{lcccc}
\hline \multirow{2}{*}{ Variable Predictor } & Equation I & \multicolumn{3}{c}{ Equation II } \\
\cline { 2 - 5 } & Coefficients & t-statistic & Coefficients & t-statistic \\
\hline HSIZE & $-0.06^{*}$ & -2.36 & $-0.08^{*}$ & -2.59 \\
EDUC & $0.05^{* *}$ & 1.75 & $0.07^{* *}$ & 1.78 \\
PARR & $0.72^{*}$ & 2.57 & $0.89^{*}$ & 3.05 \\
FMRM & -0.04 & -0.51 & -0.04 & -0.53 \\
FMRW & $0.17^{* *}$ & 1.69 & $0.17^{* *}$ & 1.75 \\
DEPR & $-0.38^{* *}$ & -1.71 & $-0.13^{*}$ & -3.60 \\
CDEPR & -28.06 & -0.70 & - & - \\
ODEPR & -28.00 & -0.70 & - & - \\
AGEH & 0.006 & 0.29 & 0.029 & 1.00 \\
(AGEH) & 2 & -0.07 & -0.0001 & -0.77 \\
PPRM & -0.00002 & -1.52 & $-0.05^{* *}$ & -1.67 \\
VLSTO & $-0.04^{* * *}$ & 0.86 & 0.001 & 1.18 \\
PLSTO & 0.001 & 1.68 & $0.13^{* *}$ & 1.80 \\
VPAST & $0.09^{* *}$ & 0.71 & - & - \\
LHOL & 0.001 & 1.60 & $0.023^{* *}$ & 1.69 \\
Intercept & $0.18^{* *}$ & -1.10 & -0.88 & -1.30 \\
R $^{2}$ & -0.57 & & 80.30 & \\
Adjusted-R & 79.50 & & 78.90 & \\
F-Statistic & 75.25 & & 37.63 & \\
N & 24.81 & 100 & \\
\hline
\end{tabular}

Note: i. *Indicates that the coefficients are significant at the $1 \%$ level.

** Indicates that the coefficients are significant at the $5 \%$ level.

***Indicates that the coefficients are significant at the $10 \%$ leve1.

ii. A dash (-) refers to the situation where corresponding variables are dropped in the equation to reduce multicollinearity. Since child and old dependency ratios are the part of composite dependency ratio, the former are dropped to avoid multicollinearity.

Next we use a logistic regression as another and alternative econometric technique to analyze the main determinants of poverty in terms of some qualitative and quantitative variables. In particular, the purpose of the model is to determine the factors that explain the probability of being poor. 
The logistic estimates of poverty determinants are reported in Table13. The empirical results show that, except for FMRM, PLSTO and PASTH, all the coefficients in the regression are significantly different from zero at the 1 to $5 \%$ level of significance. HSIZE, DEPR, HHFM, HHLB and HHRS have an odds ratio of more than 1 which confirms their positive relation with the probability of being poor. On the contrary, the variables EDUC, FMRM, HHLT, PARR, AGEH, HVHC, HHFR, HHFL, LHOL, PLSTO, and PASTH all have odds ratios lower than 1 , which means that these variables are negatively correlated with the probability of being poor.

The coefficient of HSIZE is statistically significant and has a positive sign. This implies that, with a decrease in household size, the probability of being poor will fall. The coefficient on the dependency ratio (DEPR) has a positive significant effect on poverty. The coefficient on educational attainment of households (EDUC) has a negative significant effect on poverty. This implies that the more educated an individual, the greater the potential to exploit resources and technology and avoid poverty. The coefficient of HHLT has a negative significant effect on poverty. This implies that literate households have a better chance of escaping poverty.

The participation ratio is the main component of household employment. The coefficient on PARR has a negative significant effect on being poor. It reveals that greater earnings will increase a household's income level, and that this tendency will directly alleviate poverty. Given that there is a joint family system in the rural areas of southern Punjab, the older a household head, the higher the household's earnings and accumulation of resources. This is proved empirically by the negative sign of AGEH. The coefficients of HHFR and HHFL also have a negative effect on poverty. Livelihood conditions affect the profile of poverty. The coefficient on HHRS has a positive significant effect on poverty and our result is in line with our hypothesis.

The majority of rural households are landless. The coefficient LHOL has a negative significant effect on being poor. The population of livestock plays a vital role in the rural areas of southern Punjab. Empirically, it is evident that PLSTO has a negative impact on poverty. Similarly, PASTH also has a negative relation with being a poor household. In this table, all variables have their expected signs. The results of the logistic analysis also support the results of income regression analysis. 
Table-13: Logistic Estimates of the Determinants of Rural Poverty

\begin{tabular}{lccc}
\hline Predictor & Coefficient & Z-statistic & Odds ratio \\
\hline HSIZE & $0.73^{*}$ & 2.54 & 2.47 \\
DEPR & $0.95^{*}$ & 2.59 & 2.59 \\
EDUC & $-0.28^{* *}$ & -1.96 & 0.79 \\
FMRM & -0.07 & -0.30 & 0.93 \\
HHLT & $-0.31^{* *}$ & -1.98 & 0.80 \\
HHFM & $1.11^{*}$ & 2.38 & 1.83 \\
HHFR & $-0.58^{* *}$ & -1.97 & 0.56 \\
HHFL & $-0.44^{* *}$ & -1.96 & 0.80 \\
HHLB & 0.35 & 0.68 & 1.12 \\
HHRS & $0.73^{* *}$ & 1.98 & 1.57 \\
PARR & $-2.56^{*}$ & -3.10 & 0.08 \\
AGEH & $-0.04^{*}$ & -2.56 & 0.96 \\
HVHC & $-0.58^{* *}$ & -1.98 & 0.57 \\
LHOL & $-0.69^{* *}$ & -1.96 & 0.50 \\
PLSTO & -0.03 & -1.07 & 0.98 \\
PASTH & -0.41 & -1.17 & 0.66 \\
Constant & 2.14 & 1.69 & - \\
\hline Log-likelihood $=-22.73$ & $\mathrm{n}=100$ & \\
Joint significance $=132.81, \mathrm{P}=0.000$ & \\
\hline
\end{tabular}

Notes: * Indicates that the coefficients are significant at the $1 \%$ level. ** Indicates that the coefficients are significant at the $5 \%$ level.

\section{Conclusions and Policy Implications}

In this study, we have undertaken bivariate and multivariate analyses of household socioeconomic and demographic characteristics using data from a village located in southern Punjab. The various characteristics of poor households analyzed on the basis of FGT indices in a bivariate analysis suggest the following. 
(I) It has been empirically proven that, as a household's landholdings increase, the three poverty measures, incidence, depth, and severity of poverty, decrease. This tendency shows the negative relationship between landholdings and incidence of poverty. The results also show that poverty incidence, depth, and severity are worse among landless households.

(II) A household size of 7-8 members was found to be most prone to poverty. On average, 8 and above members in a household imply the highest incidence, depth and severity of poverty. We have also concluded that an optimal household size is 3 members, as it experiences a lower depth and intensity of poverty.

(III) We have drawn a strong and significant relationship between educational attainment and rural poverty. Households with no educational attainment have the highest incidence, depth and severity of poverty. There is evidence that with a rising level of educational attainment, all three measures of poverty fall.

(IV) The evidence shows that better economic conditions are associated with greater participation rates and that poverty falls as the participation rate increases.

(V) The results also show that rural poverty was the result, as one might expect, of a high dependency ratio. Starting from the lowest dependency ratio, increasing dependency is correlated with higher of incidence of poverty, depth and severity of poverty. It also appears that the highest dependence ratios (which make up only one-third of the population) are associated with a lower level of incidence of poverty, depth and severity of poverty.

(VI) A lower female-male ratio of workers has a negative relation to incidence, depth and severity of poverty.

(VII) As far as the age of the household head is concerned, we have concluded empirically that the older the household head, the lower the incidence, depth and severity of poverty given his or her work experience. This situation might be because of the high dependency ratio and low participation rates among the households of southern Punjab.

The results of the two econometric models constructed to carry out the multivariate analysis of rural poverty are described below: 
(I) In the income regression analysis, household size, education levels, participation rates, female-male ratio of workers, dependency ratio, persons per room, population of livestock, landholding, and age of household heads were found to influence the dependent variable (household income per capita) in a significant way. An empirical enquiry revealed that household size, female-male ratio of workers, dependency ratio, persons per room and age of household heads were found to be negatively related to a household's income per capita and indirectly positively related to poverty incidence. However, educational attainment level, participation rate, population of livestock and landholdings by households were found to be positively related to their income level and inversely related to poverty incidence.

(II) We now turn to an important and alternative technique: multivariate logistic regression models in analyzing the determinants of rural poverty. The evidence shows that household size, dependency ratio, the presence of a female household head, and residence in a kacha house was positively and significantly correlated with the probability of being poor. Variables that were negatively and significantly correlated with the probability of being poor were educational attainment of households, literate household head, whether the household head is a farmer or a farm laborer, participation ratio, age of household head, household visits to a health center, and landholdings.

Poverty alleviation efforts should be made through grassroots-level planning to raise both farm and nonfarm rural real incomes. This can be done through job creation, micro- and small-scale entrepreneurship, and the increased provision of formal and informal education and health facilities, safe drinking water, improved sanitation conditions and nutrition, better housing and a variety of related social and welfare services. Moreover, measures should also be adopted to improve the economic and social infrastructure in remote areas of Pakistan. Efforts should also be made to improve the social and especially demographic characteristics of households as these are found to be important reasons for poverty in a household. The government should also allot more land to landless households to reduce poverty in southern Punjab. 


\section{References}

Ali, S. and S. Tahir, 1999, "Dynamics of Growth, Poverty and Inequality in Pakistan," The Pakistan Development Review, Vol. 38 (1), 837-857.

Amjad, R. and A. R. Kamal, 1997, "Macroeconomic Policies and Their Impact on Poverty Alleviation in Pakistan," The Pakistan Development Review, Vol. 36 (1), 39-68.

Arif, G. M, H. Nazli and R. Haq, 2000, "Rural Non-Agricultural Employment and Poverty in Pakistan," The Pakistan Development Review, Vo1. 39 (4), 1089-1110.

Arif, G. M., 2000, "Recent Rise in Poverty and its Implications for Poor Households in Pakistan,” The Pakistan Development Review, Vol. 39 (4), 1153-1170.

Booth, C., 1889, "The Life and Labor of the people," (Williams and Northgate), London.

Chakararty, S., 1983, “A New Index of Poverty," Mathematical Social Sciences, Vol. 6, 307-313. Credit, Interest and the Business Cycle, Cambridge, Harvard University Press.

Chaudhry, I. S., 2003, “An Empirical Analysis of the Determinants of Rural Poverty in Pakistan: A Case Study of Bahawalpur District with Special Reference to Cholistan," Unpublished Ph.D. Thesis, The Islamia University of Bahawalpur, Pakistan.

Clark, S., Hemming, R. and U1ph, D., 1981, "On Indices for the Measurement of Poverty,” The Economic Journal, Vol. 91, 515-526.

Deaton, A., 1997, "The Analysis of Household Surveys: A MicroEconometric Approach to Development Policy," Baltimore: The Johns Hopkins University Press.

Duclos, J. and Gregoire, P., 2002, "Absolute and Relative Deprivation and the Measurement of Poverty,” Department of Economics, University of Laval, Canada.

Federal Bureau of Statistics, 2002, "Poverty in the 1990s" PIHS, Government of Pakistan, Islamabad. 
Foster, J., Greer, J. and Thorbecker, E., 1984, "A Class of Decomposable Poverty Measures,” Econometrica, Vol. 52, 761-767.

Glewwe, P., 1990, "Investigating the Determinants of Household Welfare in Cote d' Ivoire," Living Standard Measurement Study 29. World Bank, Washington, D.C.

Government of Pakistan, 1998, "District Census Report of Muzaffargarh," Population Census Organization, Statistics Division, GOP, Islamabad.

Government of Pakistan, 2005-2006, Pakistan Economic Survey, Federal Bureau of Statistics, Islamabad.

Greene, W., 1993, "Econometric Analysis,” New York: Maxwe11 Macmillan, 2nd edition, 1993.

Grosh, M., and Munoz, J., 1996, "A Manuel for Planning and Implementing the Living Standards Measurement Study Survey 126," World Bank, Washington, D.C.

International Fund for Agricultural Development, 2001, "Rural Poverty Report-2001: The Challenge of Ending Rural Poverty," Oxford: Oxford University Press.

Irfan, M. and R. Amjad, 1984, "Poverty in Rural Pakistan,” in A. R. Khan and E. Lee (eds) Poverty in Rural Asia, Bangkok: ILO/ARTEP.

Jafri, S. M. Y., 1999, “Assessing Poverty in Pakistan,” In a Profile of Poverty in Pakistan, Mahbub-u1-Haq Center for Human Development, Islamabad.

Koze1, V., 2000, "Social and Economic Determinants of Poverty in India's Poorest Regions: Qualitative and Quantitative Assessments," in Michael Bamberger, (eds). Integrating Quantitative and Qualitative Methods in Bank Operations. World Bank, Washington, D.C.

Lipton, M., 1983, "Labor and Poverty," World Bank Staff, Working Paper 616, World Bank.

Lipton, M. and Ravallion, M., 1995, "Poverty and Policy," In Jeer Richard Beharman and Thirukodikaval Nilakanta Srrinivasam, (eds). Hand Book of Development Economics, Vol. 3. Amsterdam: Elsevier Press. 
Malik S., 1996, "Determinants of Rural poverty in Pakistan: A Micro Study," The Pakistan Development Review, Vol. 35 (2), 171-187.

Malik, M. H., 1988, "Some New Evidence on the Incidence of Poverty in Pakistan,” The Pakistan Development Review, Vol. 27 (4).

Malik, S., 1992, "A Study of Rural Poverty in Pakistan with Special Reference to Agricultural Price Policy,” Unpublished Ph.D. Thesis, University of Sussex, U.K.

Oppenheim, C. and Harker, L., 1996, "Poverty: The Facts," revised and update, 3rd Edition, Child Poverty Action Group (CPAG).

Qureshi, S., and Arif, G. M., 2001, "Profile of Poverty in Pakistan, 198899,” PIDE, Islamabad, (MIMAP Technical Paper Series No. 2).

Ravallion, M., 1996, "Issues in Measuring and Modeling Poverty," The Economic Journal, Vol. 106, 1328-1343.

Ravallion, M., and Bidani, B., 1994, "How Robust is a Poverty Profile?" World Bank Economic Review, Vol. 8 (1), 75-102.

Ravallion, M., 1993, "Poverty Comparisons," Fundamentals of Pure and Applied Economics, Vol. 56, Hardwood Academic Press, Chur, Switzerland.

Ravallion, M., 1994, "Poverty Comparisons," Chur, Switzerland: Hardwood Academic Publishers.

Ravallion, M., and Huppi, M., 1991, "Measuring Changes in Poverty: A Methodological Case Study of Indonesia During an Adjustment Period,” World Bank Economic Review, Vol. 5 (1), 57-82.

Rowntree, B.S., 1901, “Poverty: A Study of Town Life,” Macmillan.

Sen, A. K., 1976, "Poverty: an Ordinal Approach to Measurement," Econometrica, Vo1. 44, 219-231.

Sen, A. K., 1979, "Issues in the Measurement of Poverty," Scandinavian Journal of Economics, Vol. 81, 285-307.

Sen, A. K., 1981, "Poverty and Famines," Oxford: Clarendon Press. 
Sen, A. K., 1984, "Rights and Capabilities," in Amartya K. Sen, ed., Resource Values and Development, Oxford, U.K.

Sen, A. K., 1999, "Development as Freedom,” New York: Knopf Press.

Watts, H.W., 1968, “An Economic Definition of Poverty,” in D.P. Moynihan (eds.), on Understanding Poverty, New York: Basic Books.

Wodon, Q., 1997, "Food Energy Intake and Cost of Basic Needs: Measuring Poverty in Bangladesh,” Journal of Development Studies, Vol. 34 (2), 66-101.

Wodon, Q., 2000, "Micro Determinants of Consumption, Poverty, Growth and Inequality in Bangladesh," Applied Economics, Vol. 32 (1) , 1337-52.

Wodon. Q., ed., 2001, "Attacking Extreme Poverty: Learning from the International Movement ATD Fourth World,” Technical Paper No. 502, World Bank, Washington, D.C.

World Bank, 1990, “World Development Report 1990: Poverty,” New York: Oxford University Press.

World Bank, 2000, "Poverty in Pakistan: Issues, Priorities and Policy Options, a Concept Note," Paper Presented at a Seminar Held in Islamabad in September.

World Bank, 2000, “World Development Report 2000/2001: Attacking Poverty,” New York: Oxford University Press. 